Boletín de la Sociedad Geológica Mexicana

VOLUMEN 67, NÚM. 3, 2015, P. 401-412

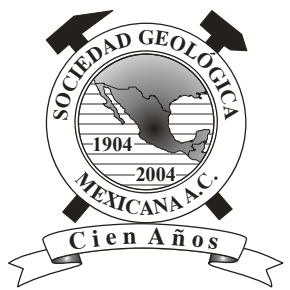

\title{
Experimental chondrules by melting samples of olivine, clays and carbon with a $\mathrm{CO}_{2}$ laser
}

\author{
Karina E. Cervantes-de la Cruz ${ }^{1,2, *}$, Fernando Ortega Gutiérrez³, Jesús Solé Viñas ${ }^{3}$, \\ Antígona Segura Peralta ${ }^{1}$, Margarita Adela Reyes Salas ${ }^{3}$, Blanca Sonia Ángeles García ${ }^{3}$, \\ María del Consuelo Macías Romo ${ }^{3}$, Carlos Linares-López ${ }^{4}$ \\ ${ }^{1}$ Departamento de Física, Facultad de Ciencias, Universidad Nacional Autónoma de México, Circuito Exterior s/n, Ciudad \\ Universitaria, Delegación Coyoacán, C.P. 04510, México D.F. \\ ${ }^{2}$ Instituto de Ciencias Nucleares, Universidad Nacional Autónoma de México, Circuito Exterior s/n, Ciudad Universitaria, Delegación \\ Coyoacán, C.P. 04510, México D.F. \\ ${ }^{3}$ Instituto de Geología, Ciudad Universitaria, Delegación Coyoacán, C.P. 04510, México D.F. \\ ${ }^{4}$ Instituto de Geofísica, Ciudad Universitaria, Delegación Coyoacán, C.P. 04510, México D.F. \\ *karina-cervantes@ciencias.unam.mx
}

\begin{abstract}
Chondrules are the major constituents of chondritic meteorites; however, their origin is still an enigma for meteoritic science. In this work we report the results of melting minerals to experimentally generate objects similar to chondrules. The degree of fusion of olivine appears to be an important factor in determining the width of the bars in samples with barred-type olivine (BO) chondrules. On the other hand, the contribution of clays and carbon (possible precursor grains) is an important factor in those experiments where the melted samples showed porphyritic texture.
\end{abstract}

Keywords: experimental chondrules, chondrites, $\mathrm{CO}_{2}$ laser.

\section{Resumen}

Los condros son los constituyentes principales de las meteoritas condríticas. Sin embargo, su formación sigue siendo un enigma para la ciencia de la meteorítica. En este trabajo se reportan los resultados de la fusión de minerales para obtener fundidos tipo condro. El grado de fusión del olivino es un factor importante para determinar el ancho de las barras de las muestras tipo condros barrados de olivino (BO). Por otra parte, la contribución de arcillas y carbón (posibles componentes de los granos precursores) es un factor importante en los experimentos en los que los fundidos generados tienen textura porfídica.

Palabras clave: condros experimentales, condritas, láser de $\mathrm{CO}_{2}$.

\section{Introduction}

In meteoritic science one of the biggest enigmas is the formation of chondrules, the nature of the precursor materials, the physical conditions (pressure, temperature and time) and the generating mechanisms (e.g. King, 1983;
Boss, 1996; Rubin, 2000; Scott, 2007; Alexander et al., 2008; Morris and Desch, 2010). In order to obtain more information about the origin of chondrules, it is necessary to describe the petrology of natural chondrules to guide experiments that are expected to reproduce the textures of natural chondrules. Through experimental research it 
is possible to simulate the conditions of melting of the chondrules and the type of cooling they have experienced. Connolly et al. (1991) suggested that the size of the precursor grains influences the texture of the chondrules. Connolly and Love (1998) proposed that "A definitive petrologic correlation between chondrule size and degree of heating would be a key discriminator for the soundness of many chondrule formation mechanisms.”

\section{Purpose}

The objective of this paper is to report the results of the experimental use of radiation from an infrared laser to melt silicates, simulating the formation of chondrules (barred and porphyritic types) by rapid heating and cooling. We do not intend to make an exhaustive analysis of the formation mechanism or properties of precursors from the results presented here. Our experiments are the starting point to guide more detailed ones, where we will be able to control and measure the chemical properties and physical conditions (pressure and temperature) of the samples. These guidelines are very important to constrain those variables that should be taken into account in our next set of experiments.

We assume that the chondrules are formed by multiple heating steps (Wasson, 1996; Rubin, 2000), and that the presence of carbon-related material as a precursor is relevant (Connolly and Hewins, 1996; Hewins, 1997; Connolly and Love, 1998). Chondrules in nature were formed in conditions of vacuum $\left(10^{-5} \mathrm{~atm}\right)$ and in relatively reducing conditions (e.g. Boss, 1996; Wasson, 1996; Alexander et al., 2008).

\section{Previous work}

Wasson (1996) and Desch et al. (2010) questioned the experiments that reproduced the formation of chondrules using furnaces, whose pulse heating and/or cooling rates were slow, because they do not take into account the actual conditions of chondrule formation. The main aspects of chondrules to be considered are (e.g. Boss, 1996; Wasson, 1996; Alexander et al., 2008; Morris and Desch, 2010):

1. The experiments must favor the retention of volatile materials such as FeS, $\mathrm{Na}$ and $\mathrm{K}$, which do not survive in conditions of heating and/or cooling that require several minutes, hours and even days to form chondrules (Lofgren and Lanier, 1988; Lofgren, 1989).

2. The relict grains and their igneous textures were formed through different heating pulses and not by monotonous cooling subsequent to a single event of heating (Hewins and Fox, 2004).

Wasson (1996) suggested that some chondrules recorded at least two heating events; however, the conditions of temperature-time of these events should allow the preservation of the volatile components. These heating events occurred before chondrules were incorporated into the chondritic parental body, in the early stage of the formation of the solar system (Hernández-Bernal and Solé, 2010; Connelly et al., 2012). An experimental insight into these radiation-structure interactions is of interest to tailor formation of these structures and to translate this knowledge in order to understand the evolution of the solar system. The first experiments that used the infrared radiation from a laser to form molten chondrule-like objects were carried out by Nelson et al. (1972), in which radial textures of pyroxene were reproduced. Droplets of alumina, enstatite, forsterite, enstatite-albite, forsterite-albite and mixtures were melted by using a $\mathrm{CO}_{2}$ laser and the initial temperatures of the melts were measured using an optical pyrometer. Blander et al. (1976) irradiated enstatite beads located at the center of a furnace with a $\mathrm{CO}_{2}$ laser. The furnace was used to control the background temperature during the experiment. The cooling time before nucleation was visually determined. The nucleation temperature of the resulting melts was calculated assuming that energy loss at the surface of the spherule occurred by radiative heat loss only and that the temperature within the spherule was approximately uniform at any given time. Contrasting these experimental results, they conclude that supercooling is an important factor contributing to the large variety of textures and crystal sizes observed in chondrules.

Eisenhour et al. (1994) used a $10 \mathrm{~W}$ argon-ion laser to irradiate olivine and pyroxene-rich assemblages. Their results determined that radiative heating may have been significant for chondrule formation as a result of the similarity of the fluffy opaque inclusions in naturally occurring and experimental solids. Thermal history of the grains during the experiment was inferred using the absorption properties of olivine. The latest experiment reported was performed by Beitz et al. (2013) using a $50 \mathrm{~W}$ $\mathrm{CO}_{2}$ laser to irradiate spinel and olivine chondrule analogs. This experiment was focused on studying the porosity in the dust rims of chondrules; therefore, petrological and chemical properties of the samples were not reported. Moreover, the pressure used to perform all these four experiments was not reported, making it difficult to assess the effect of this factor in the observed properties.

We present here the melting of minerals by means of a $\mathrm{CO}_{2}$ laser in the geochronology laboratory at Instituto de Geología, UNAM (Solé-Viñas, 2004).

\section{Experimental procedure}

To reproduce chondrules, we used natural crystals of olivine as precursor material. The crystals were obtained from spinel peridotite xenoliths from "La Olivina”, Chihuahua. La Olivina peridotite mineral modes vary between olivine 50 - 70 vol.\%, orthopyroxene 15 - 25 vol.\%, clinopyroxene, 15 - 25 vol.\% and spinel as accessory 
mineral (Nimz et al., 1993). Conditions controlled in the experiments were: chemical composition of the grains precursors, mass, size of the sample and heating time. The chemical composition of the mineral was obtained using $\mathrm{X}$-ray fluorescence (XRF), according to the methodology of Bernal and Lozano-Santacruz (2005).

The experiments were carried out at the Laboratory of Noble Gas Geochronology (Solé-Viñas, 2004). Samples were melted with a Merchantek ${ }^{\circledR}$ laser MIR10 $\mathrm{CO}_{2}$ with 50 $\mathrm{W}$ of power that emits in the infrared $(10.6 \mu \mathrm{m})$. The samples were weighted and mounted on a steel sample holder.

The melts were observed and photographed with an Olympus digital camera adapted to a LEICA binocular microscope. After that, to appreciate the external morphology and chemical composition of the melts, the samples were analyzed with a JEOL35C scanning electron microscope (SEM), which has an EDS analyzer (Instituto de Geología, Universidad Nacional Autónoma de México).

The samples EX1\#6, EX1\#7, EX1\#8, EX1\#62, EX1\#66, EX1\#94 and EX1\#95 were selected and embedded in epoxy resin and cut into thin sections with a Buehler low speed cutter at the Instituto de Astronomía, UNAM.

The chemical composition of the minerals in the melted samples was obtained with a JEOL JXA 8900R electron probe microanalyzer (EPMA) (Laboratorio Universitario de Petrología, UNAM). Analyses were conducted at 20 $\mathrm{keV}$ accelerating voltage with a beam current of $20 \mathrm{nA}$, a beam size of $1 \mu \mathrm{m}$ and $10-40 \mathrm{~s}$ counting times. Atomic number $(\mathrm{Z})$, absorption and fluorescence correction (ZAF correction) was made to all analytical data obtained, for Capoor, Ca-rich pyroxenes, and olivines. In order to avoid the $\mathrm{Na}$ and $\mathrm{K}$ loss, we used a probe current of $10 \mathrm{nA}$ for glass. Natural and synthetic phases of well-known compositions were used as standards. We critically evaluated the 306 WDS analyses based on their total stoichiometry. SEM backscattered electron (BSE) imagery was used to investigate the microtextures, porosity and mineralogy of

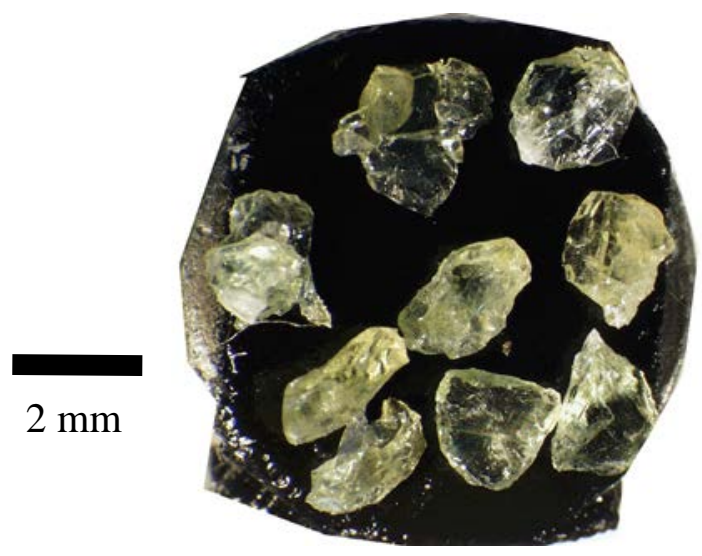

Figure 1. General aspect of olivine grains used as precursors in the experiments. The original crystals of xenoliths are 2.4 to $3 \mathrm{~mm}$ in length. The material comes from peridotites of the locality "La Olivina". the chondrules.

\subsection{Properties of the precursor}

Physical properties: The crystals of olivine used as precursor material were crushed and separated into fractions of size less than $212 \mu \mathrm{m}$, between 300 and $500 \mu \mathrm{m}$, and larger than $500 \mu \mathrm{m}$ (Figure 1, Table 1). Activated carbon was mixed with clays and milled to obtain powders of 300 $\mu \mathrm{m}$ in grain diameter.

Chemical properties: The olivine concentrate was analyzed by means of $\mathrm{X}$-ray fluorescence. The average content of forsterite $(\mathrm{Fo}=\mathrm{Mg} /(\mathrm{Mg}+\mathrm{Fe})$ ) is $91.6 \mathrm{~mol} \%$ (Table 2). On the other hand, the coal we used is a bituminous activated carbon in the form of pellets and combined with clay. Clay minerals are present in meteorites, for example smectite, serpentine and clinochlore found in Tagish Lake (Zolensky et al., 2002).

\subsection{Experimental Conditions}

In total, 11 samples of olivine were melted at ambient temperature and pressure. Room temperatures have been used in other experiments performed with lasers to simulate chondrule formation (Nelson et al., 1972; Beitz et al., 2013). In particular, Nelson et al. (1972) used a cool (300 $\mathrm{K})$ and a high $(2000 \mathrm{~K})$ background temperature for their experiments finding no significant effect in the resulting textures. Following other authors, we performed our experiments at $1 \mathrm{~atm}$ (e.g. Hewins et al., 1982; Yu et al., 2003; Hewins et al., 2005).

The conditions of power and size of the laser beam were different for each sample (Tables 1 and 2). The diameter of the laser beam varied between 1000 and $2540 \mu \mathrm{m}$, and the power was between 8 and $25.8 \mathrm{~W}$. The energy of the system was calculated on the basis of the irradiation time. Two of the samples (EX1\#6 and EX1\#7) were dusts of olivine under $212 \mu \mathrm{m}$, seven of the samples were single crystals of olivine with sizes between 776 and $2093 \mu \mathrm{m}$ (EX1\#8, EX1\#60, EX1\#61, EX1\#62, EX1\#65, EX1\#66, EX1\#67, Figure 1). Finally, two of the samples (EX1\#94 and EX1\#95) were mixed (1:1) and activated carbon contaminated with clays $(300-500 \mu \mathrm{m})$ in order to maintain as low as possible the fugacity of oxygen during the melting process. Selected sample weights were chosen to obtain melted spheres with diameters $c a$. one millimeter (taking into account that the density of the olivine is $3.22 \mathrm{~g} \mathrm{~cm}^{-3}$ for forsterite and 4.39 $\mathrm{g} \mathrm{cm}^{-3}$ for fayalite).

The melting time of the experiments was measured starting when the laser was turned on and reached the sample, and until the laser was turned off. Some samples were irradiated twice; during the second time, the interval was usually shorter than the first irradiation time (Table 2). The power of the beam was increased gradually from $2-3 \mathrm{~W}$ to maximum values (Table 2 ). Only some samples were re-melted using a higher power compared to the first 
Table 1. The table shows physical characteristics of precursor material and experimental conditions of fusion. Some of the samples that were melted more than once have two values in the power of the beam, the second being the last power supplied.

\begin{tabular}{|c|c|c|c|c|c|c|c|c|c|c|}
\hline \multirow{3}{*}{\multicolumn{2}{|c|}{$\begin{array}{c}\text { Precursor type } \\
\text { Sample } \\
\text { EX1\# } \\
\text { Ol }\end{array}$}} & \multirow{3}{*}{$\begin{array}{c}\text { Precursor } \\
\text { weight } \\
\quad(\mathrm{mg})\end{array}$} & \multirow{3}{*}{$\begin{array}{r}\begin{array}{c}\text { Melt } \\
\text { weight }\end{array} \\
\\
(\mathrm{mg})\end{array}$} & \multicolumn{7}{|c|}{ Laser conditions } \\
\hline & & & & \multicolumn{4}{|c|}{ Precursor size $(\varphi)$} & \multirow[b]{2}{*}{$\begin{array}{l}\text { Beam } \\
\text { Diam } \\
(\mu \mathrm{m})\end{array}$} & \multirow[b]{2}{*}{$\begin{array}{l}\text { Melt } \\
\text { time (s) }\end{array}$} & \multirow[b]{2}{*}{$\begin{array}{l}\text { Fusion } \\
\text { degree }\end{array}$} \\
\hline & & & & $<212 \mu \mathrm{m}$ & $\begin{array}{c}300-500 \\
\mu \mathrm{m}\end{array}$ & $>500 \mu \mathrm{m}$ & $\begin{array}{c}\text { Power } \\
\text { (W) }\end{array}$ & & & \\
\hline \multirow{3}{*}{ Dust } & 6 & 7.15 & 5.87 & 200 & & & 22 & 2120 & & Total \\
\hline & & & & & & & 23 & & & \\
\hline & 7 & 9.214 & 4.86 & 200 & & & 20.3 & 1560 & & Sintered \\
\hline \multirow{11}{*}{ Crystal } & 60 & 0.958 & 0.95 & & & 837 & 20 & 1000 & 60 & Total \\
\hline & & & & & & & 10 & & 30 & \\
\hline & 61 & 5.48 & 5.4 & & & 1485 & 15.8 & 1000 & 14 & Total \\
\hline & & & & & & & 15.8 & & 1 & \\
\hline & 62 & 6.732 & 6.65 & & & 1542 & 18 & 2120 & 2 & Total \\
\hline & & & & & & & 25.7 & 2400 & 2 & \\
\hline & 8 & 0.82 & 0.8 & & & 750 & 7.5 & 1000 & 50 & Partial \\
\hline & 65 & 8.126 & 6.76 & & & 1659 & 15 & 2540 & & Total \\
\hline & & & & & & & 17.8 & 2102 & & \\
\hline & 66 & 1.806 & 1.8 & & & 1500 & 10.2 & 1000 & 60 & Partial \\
\hline & 67 & 0.848 & 0.84 & & & 776 & 8 & 1000 & 60 & Total \\
\hline \multirow{3}{*}{$\begin{array}{l}\text { Dust and } \\
\text { activated } \\
\text { carbon }\end{array}$} & 94 & 5.474 & & & 300 & & 14 & 2120 & & Total \\
\hline & & & & & & & 15.18 & & 3 & \\
\hline & 95 & 19.382 & 16.24 & & 300 & & 19.9 & 2540 & & Total \\
\hline
\end{tabular}

Table 2. Chemical analysis of the olivine used as precursor material in this work by means of X-ray fluorescence.

\begin{tabular}{|c|c|c|c|}
\hline $\begin{array}{c}\text { Sample } \\
\text { Oxide }\end{array}$ & $\begin{array}{c}\text { Olivine } \\
\text { precursor } \\
\text { wt. } \% \\
\end{array}$ & Cation & 4 oxygen \\
\hline $\mathrm{SiO}_{2}$ & 40.43 & $\mathbf{S i}$ & 0.99 \\
\hline $\mathrm{TiO}_{2}$ & 0.01 & $\mathbf{T i}$ & 0.00 \\
\hline $\mathbf{A l}_{2} \mathbf{O}_{3}$ & 0.23 & Al & 0.01 \\
\hline $\mathrm{Cr}_{2} \mathrm{O}_{3}$ & 0.03 & $\mathrm{Cr}$ & 0.00 \\
\hline $\mathrm{Fe}_{2} \mathrm{O}_{3}$ & 1.01 & $\mathrm{Fe}^{+3}$ & 0.02 \\
\hline $\mathrm{FeO}$ & 8.13 & $\mathbf{F e}$ & 0.17 \\
\hline MnO & 0.12 & Mn & 0.00 \\
\hline MgO & 49.74 & Mg & 1.81 \\
\hline $\mathrm{CaO}$ & 0.09 & $\mathbf{C a}$ & 0.00 \\
\hline $\mathrm{NaO}$ & $<0.01$ & & \\
\hline $\mathbf{K}_{2} \mathbf{O}$ & 0.01 & & \\
\hline $\mathbf{P}_{2} \mathbf{O}_{5}$ & 0.01 & & \\
\hline NiO & 0.15 & & \\
\hline \multirow[t]{3}{*}{ Total } & 99.99 & Total & 3.00 \\
\hline & & Fo (mol \%) & 91.6 \\
\hline & & $\mathrm{Fa}(\mathrm{mol} \%)$ & 8.4 \\
\hline
\end{tabular}

irradiation (Table 2).

\section{Results}

5.1 Textures of the melted samples

\subsubsection{Barred Olivine-like samples}

In this work we use the texture description of olivine dendrites by Faure et al. (2003a; 2003b) who developed a model to correlate olivine morphology as a function of cooling rate and degree of undercooling. Morphology of dendrites as a function of increased undercooling parameter follows the sequence: tablet $\rightarrow$ hopper crystal (hourglass shape) $\rightarrow$ incipient dendrite (baby swallowtail crystal) $\rightarrow$ dendrite (swallowtail morphology). Lattice olivine, chain olivine and branching olivine represent different cross-sections of the same kind of dendrite fiber (Faure et al., 2003a). The growth of dendrites is the result of the propagation of small aligned hopper crystals to form the dendritic fibers; we use "bar" as a synonym for those dendritic fibers. 
Crystals grew radially and bars intersected in one or more points (EX1\#6, EX1\#60, EX1\#8, EX1\#61, EX1\#62, EX1\#66, EX1\#65, EX1\#67, EX1\#94; Figures 2a, 10). The parameters measured were the thickness and the separation of the olivine bars. Variations in these parameters were related to the power of the laser beam applied in their last warming-up event (Table 3, Figure 11). Samples EX1\#62, EX1\#6, EX1\#65 and EX1\#61 presented huge olivine bars with several microns of empty space in between each bar
(Figures 2, 3, 4, and 5, respectively). Sample EX1 \#62 presents coarse bars $(250 \mu \mathrm{m})$ with two sets of orientation; the first set is composed of four bars almost parallel to each other; the second is composed of three bars perpendicular to the previous set. Samples EX1\#6, EX1\#65 and EX1\#61 exhibit bars and empty spaces thinner than in EX1\#62. All samples show olivine bars intercepted by each other.

We observed prismatic crystallites of olivine with well-developed faces at their endings between the bars of
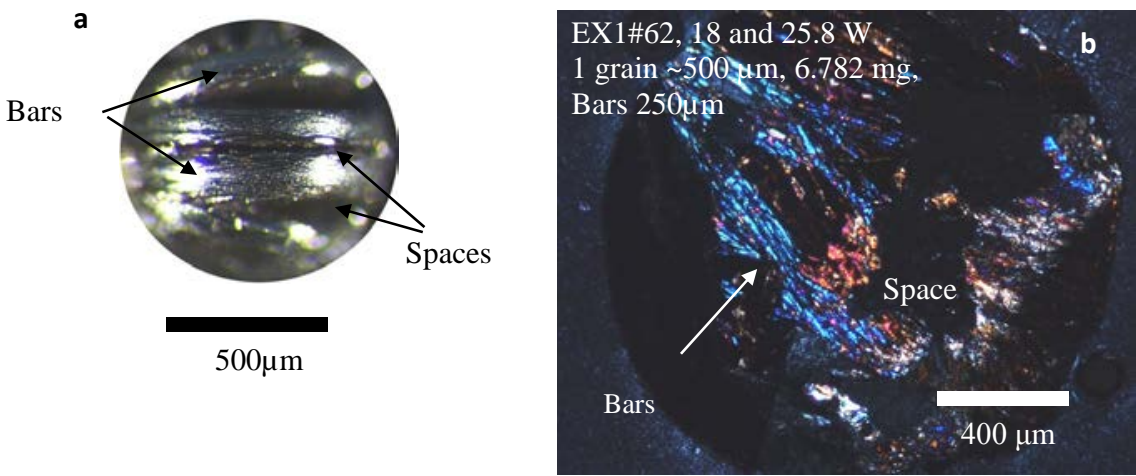

Figure 2. View of sample EX1\#62. Laser power, in the last melt was $25.8 \mathrm{~W}$. a) View of the sample. b) Photomicrograph of a thin section under crossed Nicols. The width of the bars is up to $250 \mu \mathrm{m}$. Note the presence of empty space between each bar.
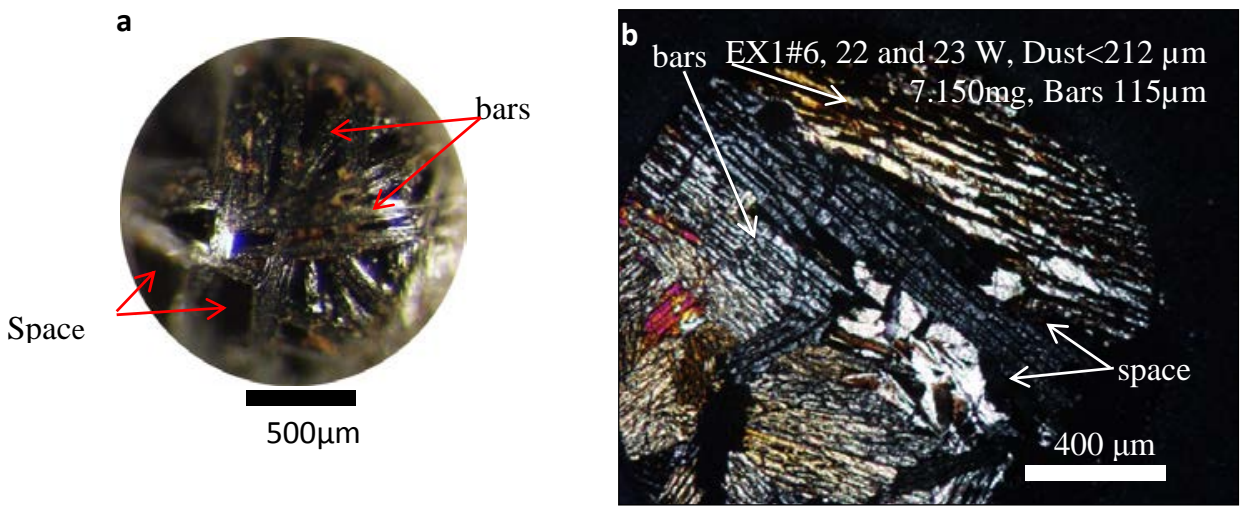

Figure 3. Photomicrographs of the sample EX1\#6. Maximum laser power was 23 W. a) View of the heated sample. b) Photomicrograph of a thin section under crossed Nicols. The width of the bars is up to $115 \mu \mathrm{m}$, and there is an empty space between each bar.
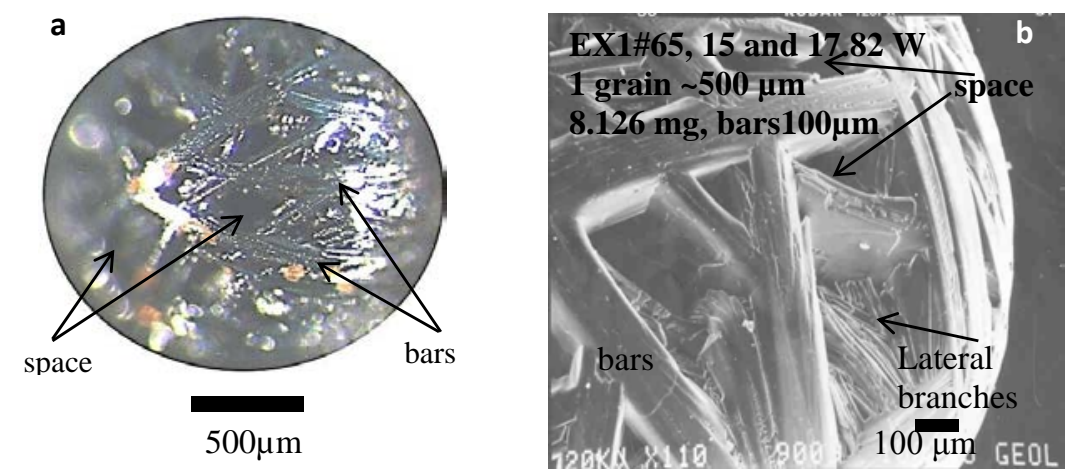

Figure 4. Images of sample EX1\#65. Maximum power was $17.82 \mathrm{~W}$. a) View of the sample. b) Backscattered electron image (SEM) of the surface of the sample. Note the dendritic fibers between bars (width of the bars is up to $100 \mu \mathrm{m}$ ). 

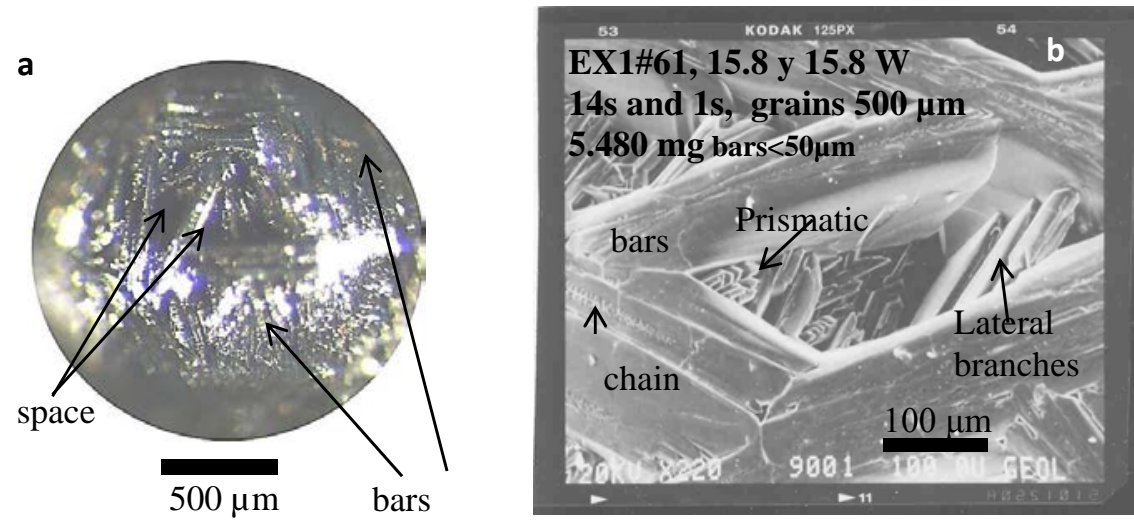

Figure 5. Images of the sample EX1\#61. Maximum power was $15.8 \mathrm{~W}$. a) The sample shows the presence of very thin bars. b) Backscattered electron (BSE) image showing a detail of this sample. The width of the bars is up to $50 \mu \mathrm{m}$, with a dendritic fibers.

Table 3. Textural features of the melts in accordance to the laser power arranged by bar size. The textural terms are those described in Donaldson, 1976.

\begin{tabular}{|c|c|c|c|c|c|c|c|c|c|c|c|}
\hline $\begin{array}{c}\text { Sample } \\
\text { EX1\# }\end{array}$ & $\# 62$ & \#6 & $\# 65$ & $\# 61$ & \#66 & $\# 60$ & $\# 67$ & $\# 8$ & $\# 7$ & \#94 & \#95 \\
\hline Laser power (W) & 25.8 & 23 & 17.8 & 15.8 & 10.2 & 10 & 8 & 7.5 & 20.3 & 14 & 19.9 \\
\hline $\begin{array}{c}\text { Bar size } \\
(\mu \mathrm{m})\end{array}$ & 200 & 130 & 120 & 80 & 30 & 30 & 29 & 23 & - & $\begin{array}{c}\mathrm{Ol} \text { and px } \\
\text { crystals }\end{array}$ & - \\
\hline $\begin{array}{l}\text { Gap between bars } \\
\qquad(\mu \mathrm{m})\end{array}$ & 200 & 180 & 110 & $\begin{array}{l}\text { Rhombus } \\
\text { are formed }\end{array}$ & 0 & 0 & 0 & 0 & - & 0 & 0 \\
\hline Surface texture & $\begin{array}{l}\text { with } \\
\text { spaces } \\
\text { between } \\
\text { parallel } \\
\text { bars }\end{array}$ & $\begin{array}{l}\text { Radial } \\
\text { bars to } \\
\text { many } \\
\text { points } \\
\text { with } \\
\text { spaces } \\
\text { between } \\
\text { parallel } \\
\text { bars }\end{array}$ & $\begin{array}{l}\text { Radial } \\
\text { bars to } \\
\text { many } \\
\text { points } \\
\text { with } \\
\text { spaces } \\
\text { between } \\
\text { parallel } \\
\text { bars, } \\
\text { plates of } \\
\text { olivine } \\
\text { growing } \\
\text { between } \\
\text { the bars }\end{array}$ & $\begin{array}{l}\text { Intersecting } \\
\text { bars with } \\
\text { spaces in } \\
\text { the form of } \\
\text { rhombus, } \\
\text { plates of } \\
\text { olivine } \\
\text { growing } \\
\text { between } \\
\text { the bars }\end{array}$ & $\begin{array}{l}\text { Chains of } \\
\text { olivine }\end{array}$ & $\begin{array}{l}\text { Olivine } \\
\text { lateral } \\
\text { branches } \\
\text { with } \\
\text { chains of } \\
\text { olivine }\end{array}$ & $\begin{array}{l}\text { Chains of } \\
\text { olivine } \\
\text { and } \\
\text { dendritic } \\
\text { textures }\end{array}$ & $\begin{array}{l}\text { Chains of } \\
\text { olivine } \\
\text { and } \\
\text { dendritic } \\
\text { textures }\end{array}$ & $\begin{array}{l}\text { Dendritic } \\
\text { textures }\end{array}$ & $\begin{array}{l}\text { Euhedral } \\
\text { crystals } \\
\text { with } \\
\text { tetragonal } \\
\text { pinacoids }\end{array}$ & $\begin{array}{l}\text { Vitreous } \\
\text { texture }\end{array}$ \\
\hline
\end{tabular}

samples EX1\#65 and EX1\#61. Those bars are connected by lateral branches and chain olivine according to the dendrite morphology used by Faure et al. (2003a, b) (Figure 4 and 5, respectively). The final power of the beam supplied to melt these samples ranged between 25.8 and $15.8 \mathrm{~W}$ (see Table 3).

The bars of samples EX1\#67, EX1\#60, and EX1\#8 did not have empty spaces in between (Figure 6 and 7). These bars showed different orientations. A study by SEM revealed that chain olivine morphology is common (Figure 6). The experiment EX1\#8 presents thin chains of olivine. Cross sections of these samples showed dove-shape crystals and the rim of the sphere clearly differentiated from the interior of the melt (Figure 7). The final power of the beam used to irradiate samples was between 10 and $7.5 \mathrm{~W}$ (see Table 3).

\subsubsection{Porphyritic-like samples}

The samples with carbon presented a porphyritic texture (EX1\#94, EX1\#95; Figures 8a, b). Sample EX1\#94 was irradiated twice while EX1\#95 was melted only once. Crystals of olivine and pyroxene were formed when sample EX1\#94 was melted down for the second time. To melt these samples the final power of the beam was 20 and $14 \mathrm{~W}$, respectively (see Table 3). Remarkably, in samples EX1\#94 and EX1\#95 the melting occurred more rapidly in contrast with the samples without carbon, showing a barred olivine morphology. Sample EX1\#95 presented a degassing of the material. A more detailed inspection through the SEM of sample EX1\#94 showed a vitreous and phenocrystalline portion of the porphyritic surface. The hemisphere that was exposed during a second irradiation of the laser beam 

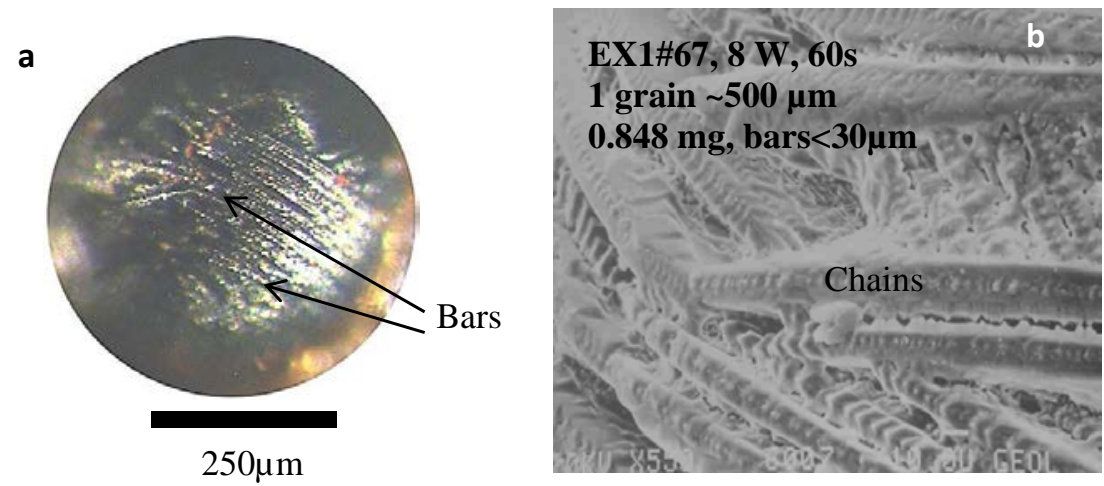

Figure 6. Images of the sample EX1\#67. Maximum laser power was $8 \mathrm{~W}$. a) An overview of the sample after heating. b) BSE image showing in detail the dendritic texture of the sample: bars and chains on the bars. Note the absence of empty space in between bars (up to $30 \mu \mathrm{m}$ thick).

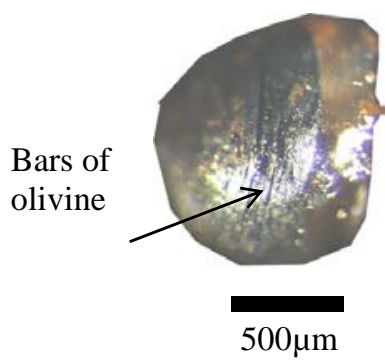

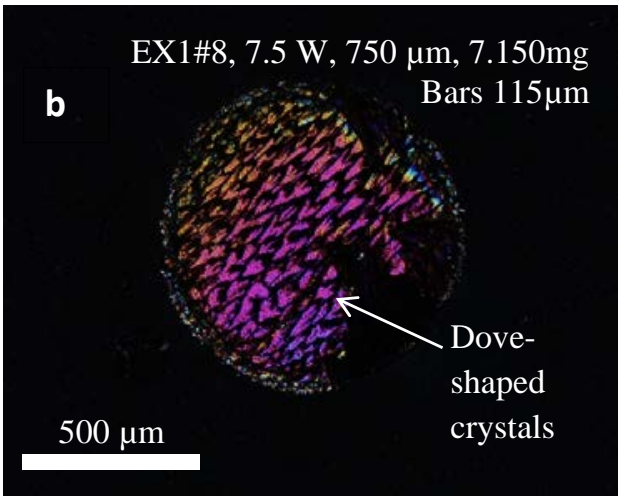

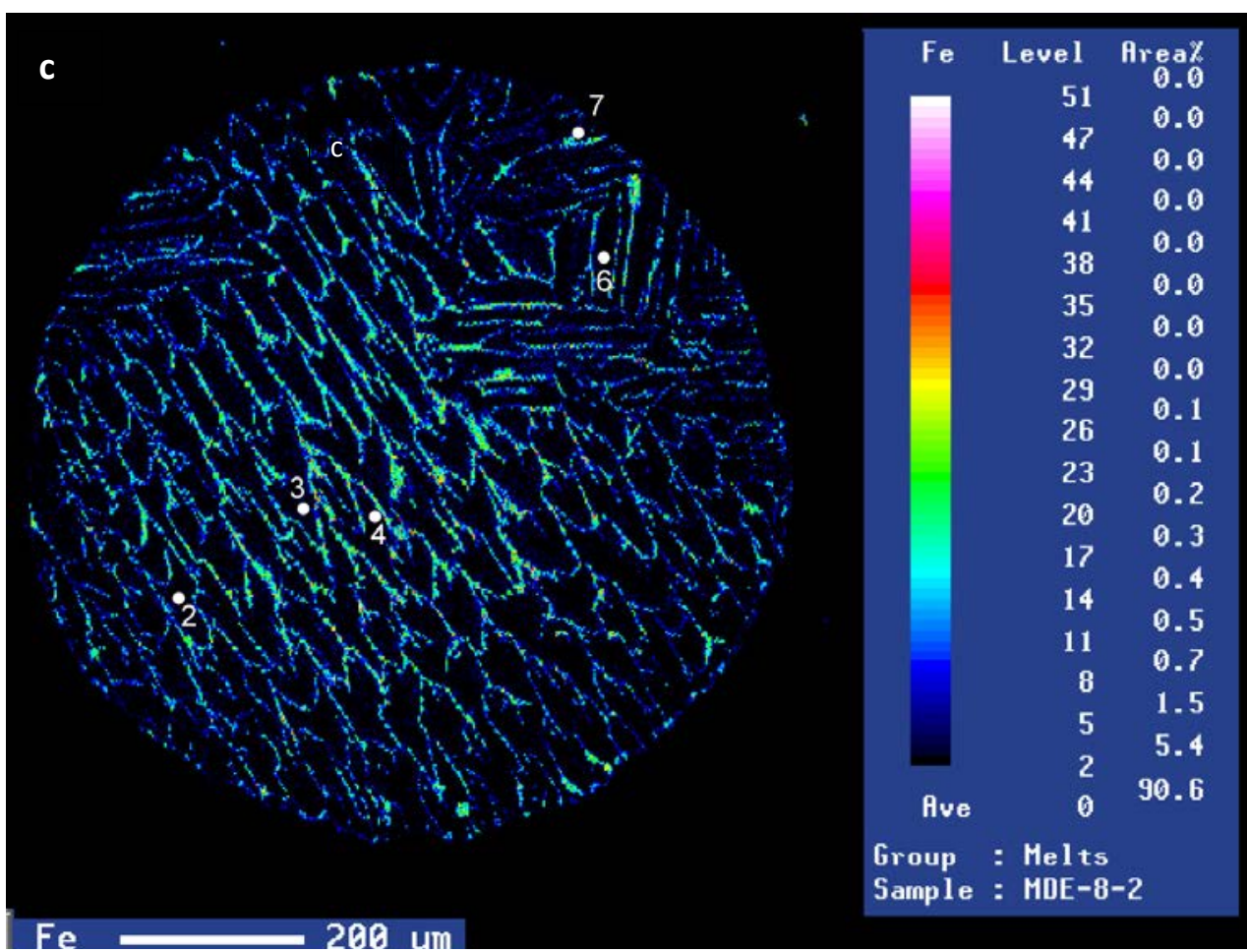

Figure 7. Picture of the experiment EX1\#8. Maximum laser power was $7.5 \mathrm{~W}$. a) An overview of the sample after heating. b) Note the dove-shaped crystals of the sample (with olivine bars reaching up to $23 \mu \mathrm{m}$ wide) and a well-defined edge ring. Photomicrograph taken with polarized light. c) The compositional image (EPMA) of the sample EX1\#8 shows the distribution of iron. Note that the cyan edges of the dove-shape crystals of olivine are enriched in this element. The numbers in the figure refer to the name of sample in Table 4. 
showed skeletal crystals (Figure 9). Crystals of olivine show chain-like morphology (Figure 9).

\subsection{Chemical analyses of samples}

Samples EX1\#8 and EX1\#94 were analyzed by means of EPMA (Table 4 and 5). The microanalyses of EX1\#8 are representative of the samples with barred textures. Bars have a chemical zoning; dove-shape crystal cores are enriched in magnesium (Fo 94 mol \%) whereas the edges of the dove-shape crystals are enriched in iron (Fo $82 \mathrm{~mol}$ $\%$ ), especially near the surface of the sphere (Fo $65 \mathrm{~mol} \%$ ). The image taken with EPMA exhibits the iron-rich zones in cyan tones, corresponding to the edges of the dove shape olivine crystals (Figure 7c).

The melt EX1\#94 is representative of the porphyritic textures. Olivine and pigeonite phenocrysts were found near the surface of the sample (Figure $8 \mathrm{a}$ and b). Figure 9 showed phenocrysts of olivine embedded in glass for sample EX1\#94. Olivine presents homogeneous composition (Fo $91 \mathrm{~mol} \%$ ) (Table 5; Figure 10). Crystals of olivine had straight edges with respect to the glass of the sample. Near the surface, olivine phenocrysts exhibited reaction bays and elongated crystals of olivine (Fo $96 \mathrm{~mol} \%$ ) interspersed with internal lamellae of pigeonite ( En 79 mol \%, Wo 6 mol \%, see Table 6; Figure 10). Figure 10 shows that the edges of the crystals of olivine react with the glass. This reaction results in pigeonite lamellae and $\mathrm{MgO} \%$-enriched olivine. The composition of the glass is homogeneous and is enriched in iron and magnesium oxides ( $\sim$ and $\sim 30 \mathrm{wt}$ $\%$, respectively, Table 7). The compositional image taken by EPMA shows the distribution of magnesium, with the olivine core enriched in this element (Figure 9).

Table 4 shows that the sample EX1\#8 retained volatile elements ( $\mathrm{Na}$ and $\mathrm{K}$ ) although they are not homogeneously distributed in the sample. The dove-shape textures show a depletion of these compounds in their cores and enrichment at the edges.

\section{Discussion}

\subsection{Barred olivine-like samples}

There is a clear relationship between the morphology of the samples and the beam power applied. The samples melted with a beam power greater than $15 \mathrm{~W}$, and developed pronounced variable (from 20 to $200 \mu \mathrm{m}$ ) empty spaces between olivine bars. There is a negative correlation between the amount of olivine bars and the decreasing power of the beam. Furthermore, there is a positive correlation between the width of the bars and the increasing laser power (see Figures $2-7$ and 11). The samples showing narrow gaps between bars correspond to beam powers lower than 11 $\mathrm{W}$. We found that the bar size is a function of the applied power of the laser beam $\left(y=10.337 e^{0.1182 x}\right.$, Figure 11). This corresponds to the number of crystallization nuclei that survives due to the high energy applied. Other experiments, using laser, confirmed that the cooling rates are related to the size of the crystals (Nelson et al., 1972; Blander et al., 1976), however, these results cannot be directly compared with ours because their system contains enstatite.

According to the experiments by Faure and collaborators (2003b), to form dendritic crystals similar to those obtained in this work, it is necessary that the material exceeds the liquidus temperature of the CMAS system (CalciumMagnesium-Aluminum-Silica; $\mathrm{T}_{\text {liq }}=1342{ }^{\circ} \mathrm{C}$ ) to $1400^{\circ} \mathrm{C}$ with cooling rates of $\sim 1890^{\circ} \mathrm{C} / \mathrm{h}$, these experiments lasted 24 hours. According to the olivine morphology model, Faure et al. (2003a; b) found that olivine dendrites (swallowtail morphology) are formed by a rapid growth regime. This fast crystallization is mainly influenced by the degree of undercooling with minor influence of cooling rate.

On the other hand, the model by Lofgren (1996), based on several experiments reported in the literature, suggests that the chondrules were melted at temperatures ranging from
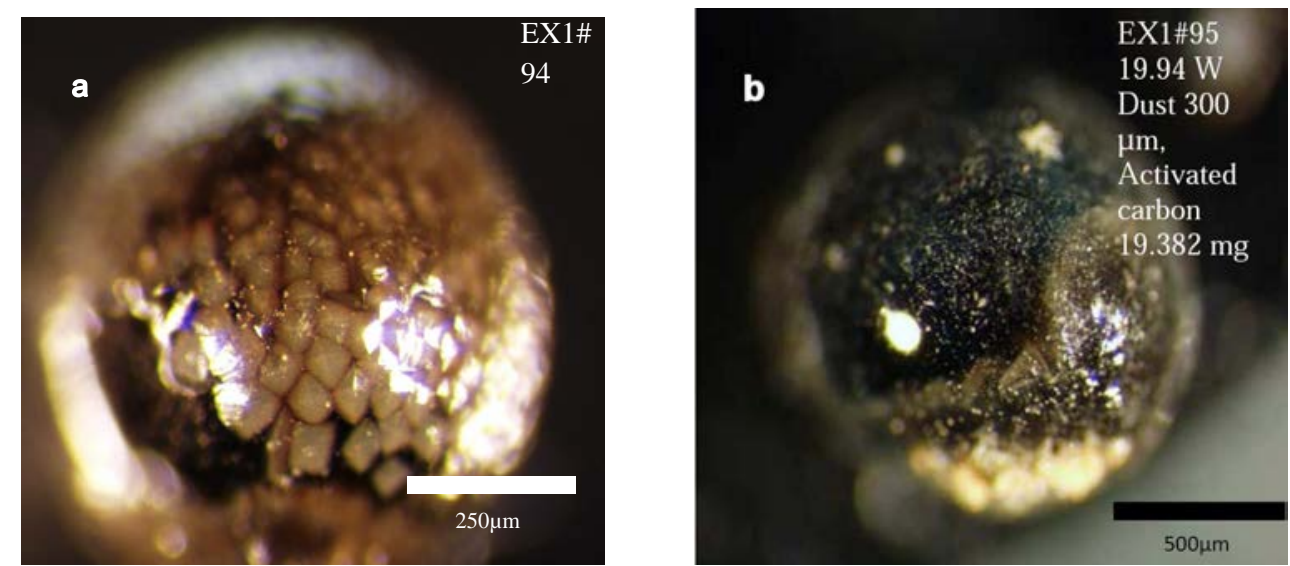

Figure 8. Pictures taken under binocular microscope. a) Sample EX1\#94 with porphyritic texture: crystals of olivine and pyroxene are surrounded by a vitreous matrix. (b) Sample EX1\#95 shows a vitreous surface with small crystals in its interior. The clear zone observed in the lower part of the sphere, corresponds to a vacuole with $\mathrm{CO}_{2}$ resulting from the mixture of the olivine with activated carbon. 
Table 4. Representative olivine compositions of experimental melts.

\begin{tabular}{|c|c|c|c|c|c|c|c|c|}
\hline $\begin{array}{l}\text { Sample } \\
\text { wt. \% }\end{array}$ & $\begin{array}{l}\text { EXxp1\# } \\
8-0-2\end{array}$ & $\begin{array}{l}\text { EX1\# } \\
8-0-3\end{array}$ & $\begin{array}{l}\text { EX1\# } \\
8-0-4\end{array}$ & $\begin{array}{l}\text { EX1\# } \\
8-0-6\end{array}$ & $\begin{array}{l}\text { EX1\# } \\
\text { 8-0-7 }\end{array}$ & $\begin{array}{l}\text { EX1\# } \\
94-0-1\end{array}$ & $\begin{array}{l}\text { EX1\# } \\
94-0-5\end{array}$ & $\begin{array}{l}\text { EX1\# } \\
\text { 94-0-6 }\end{array}$ \\
\hline$\overline{\mathrm{SiO}_{2}}$ & 40.88 & 41.06 & 39.63 & 40.98 & 33.07 & 40.79 & 40.94 & 40.31 \\
\hline $\mathrm{TiO}_{2}$ & 0.00 & 0.00 & 0.00 & 0.00 & 0.00 & 0.00 & 0.00 & 0.00 \\
\hline $\mathrm{Al}_{2} \mathbf{O}_{3}$ & 0.01 & 0.01 & 0.03 & 0.03 & 0.32 & 0.10 & 0.12 & 0.00 \\
\hline $\mathrm{Cr}_{2} \mathrm{O}_{3}$ & & & & & & 0.00 & 0.00 & 0.00 \\
\hline $\mathrm{Fe}_{2} \mathrm{O}_{3}$ & & & & & & 0.00 & 0.00 & 0.00 \\
\hline $\mathrm{FeO}$ & 7.04 & 6.49 & 17.07 & 5.97 & 32.49 & 3.88 & 4.06 & 8.79 \\
\hline MnO & 0.12 & 0.11 & 0.20 & 0.11 & 0.24 & 0.05 & 0.04 & 0.09 \\
\hline MgO & 52.43 & 53.57 & 42.76 & 53.15 & 34.76 & 53.79 & 54.13 & 49.64 \\
\hline NiO & 0.32 & 0.23 & 0.24 & 0.25 & 0.20 & 0.55 & 0.56 & 0.35 \\
\hline $\mathrm{CaO}$ & 0.02 & 0.02 & 0.07 & 0.02 & 0.02 & 0.02 & 0.05 & 0.05 \\
\hline $\mathrm{Na}_{2} \mathrm{O}$ & 0.01 & 0.00 & 0.00 & 0.00 & 0.03 & 0.01 & 0.02 & 0.03 \\
\hline $\mathbf{K}_{2} \mathbf{O}$ & 0.02 & 0.01 & 0.00 & 0.00 & 0.01 & 0.00 & 0.01 & 0.00 \\
\hline$\Sigma$ wt. $\%$ & 100.83 & 101.50 & 100.00 & 100.50 & 101.13 & 99.18 & 99.91 & 99.26 \\
\hline $\mathbf{S i}$ & 0.98 & 0.98 & 1.00 & 0.98 & 0.91 & 0.99 & 0.98 & 0.99 \\
\hline $\mathbf{T i}$ & 0.00 & 0.00 & 0.00 & 0.00 & 0.00 & 0.00 & 0.00 & 0.00 \\
\hline $\mathbf{A l}_{T}$ & 0.00 & 0.00 & 0.00 & 0.00 & 0.01 & 0.00 & 0.00 & 0.00 \\
\hline $\mathrm{Cr}$ & 0.00 & 0.00 & 0.00 & 0.00 & 0.00 & 0.00 & 0.00 & 0.00 \\
\hline $\mathrm{Fe}^{+3}$ & 0.00 & 0.00 & 0.00 & 0.00 & 0.00 & 0.00 & 0.00 & 0.00 \\
\hline $\mathrm{Fe}^{+2}$ & 0.14 & 0.13 & 0.36 & 0.12 & 0.74 & 0.08 & 0.08 & 0.18 \\
\hline Mn & 0.00 & 0.00 & 0.00 & 0.00 & 0.01 & 0.00 & 0.00 & 0.00 \\
\hline Mg & 1.88 & 1.90 & 1.62 & 1.90 & 1.42 & 1.94 & 1.94 & 1.82 \\
\hline $\mathrm{Ni}$ & 0.01 & 0.00 & 0.01 & 0.01 & 0.00 & 0.01 & 0.01 & 0.01 \\
\hline $\mathrm{Ca}$ & 0.00 & 0.00 & 0.00 & 0.00 & 0.00 & 0.00 & 0.00 & 0.00 \\
\hline $\mathrm{Na}$ & 0.00 & 0.00 & 0.00 & 0.00 & 0.00 & 0.00 & 0.00 & 0.00 \\
\hline $\mathbf{K}$ & 0.00 & 0.00 & 0.00 & 0.00 & 0.00 & 0.00 & 0.00 & 0.00 \\
\hline$\Sigma$ cation & 3.01 & 3.02 & 2.99 & 3.01 & 3.09 & 3.00 & 3.01 & 3.00 \\
\hline Fo & 93 & 94 & 82 & 94 & 65 & 96 & 96 & 91 \\
\hline $\mathbf{F a}$ & 7 & 6 & 18 & 6 & 35 & 4 & 4 & 9 \\
\hline$\# \mathbf{M g}$ & 93 & 94 & 82 & 94 & 66 & 96 & 96 & 91 \\
\hline
\end{tabular}

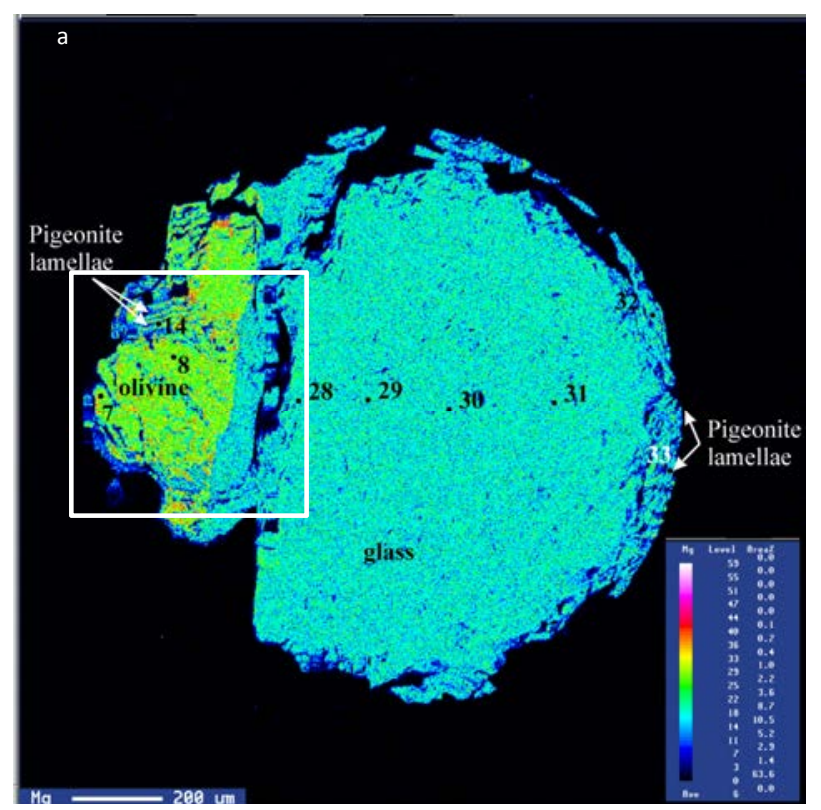

Figure 9. Experiment EX1\#94 showing porphyritic texture; the crystalline part shows skeletal olivine embedded in glass. EPMA compositional map showing the distribution of magnesium. The crystals of olivine and pigeonite (in shades of green and yellow) have high magnesium content as compared to the vitreous matrix (in cyan tones).
Table 5. Representative chemical compositions of olivine melts obtained in the present study.

\begin{tabular}{|c|c|c|c|c|c|c|c|c|c|}
\hline $\begin{array}{l}\text { Sample } \\
\text { wt. \% }\end{array}$ & $\begin{array}{l}\text { EX1\# } \\
940-7\end{array}$ & $\begin{array}{l}\text { EX1\# } \\
940-8\end{array}$ & $\begin{array}{l}\text { EX1\# } \\
940-9\end{array}$ & $\begin{array}{l}\text { EX1\# } \\
940-10\end{array}$ & $\begin{array}{l}\text { EX1\# } \\
940-11\end{array}$ & $\begin{array}{l}\text { EX1\# } \\
940-13\end{array}$ & $\begin{array}{l}\text { EX1\# } \\
940-15\end{array}$ & $\begin{array}{l}\text { EX1\# } \\
940-17\end{array}$ & $\begin{array}{l}\text { EX1\# } \\
\text { 94ol-23 }\end{array}$ \\
\hline $\mathrm{SiO}_{2}$ & 39.70 & 40.15 & 40.04 & 40.19 & 40.89 & 40.33 & 41.52 & 41.60 & 41.13 \\
\hline $\mathrm{TiO}_{2}$ & 0.00 & 0.00 & 0.01 & 0.02 & 0.01 & 0.00 & 0.00 & 0.01 & 0.01 \\
\hline $\mathbf{A l}_{2} \mathbf{O}_{3}$ & 0.01 & 0.00 & 0.00 & 0.00 & 0.27 & 0.18 & 0.55 & 0.68 & 0.42 \\
\hline $\mathrm{Cr}_{2} \mathrm{O}_{3}$ & 0.00 & 0.00 & 0.00 & 0.00 & 0.00 & 0.00 & 0.00 & 0.00 & 0.00 \\
\hline $\mathrm{Fe}_{2} \mathrm{O}_{3}$ & 0.00 & 0.00 & 0.00 & 0.00 & 0.00 & 0.00 & 0.00 & 0.00 & 0.00 \\
\hline $\mathrm{FeO}$ & 8.60 & 8.78 & 8.85 & 8.84 & 4.15 & 4.80 & 4.41 & 4.49 & 3.98 \\
\hline MnO & 0.12 & 0.10 & 0.08 & 0.08 & 0.06 & 0.05 & 0.06 & 0.05 & 0.06 \\
\hline MgO & 50.29 & 49.66 & 49.84 & 49.72 & 53.56 & 53.01 & 52.42 & 51.98 & 52.99 \\
\hline $\mathrm{NiO}$ & 0.42 & 0.39 & 0.39 & 0.37 & 0.50 & 0.43 & 0.45 & 0.50 & 0.50 \\
\hline $\mathrm{CaO}$ & 0.06 & 0.06 & 0.07 & 0.06 & 0.08 & 0.07 & 0.17 & 0.27 & 0.13 \\
\hline $\mathrm{Na}_{2} \mathrm{O}$ & 0.03 & 0.01 & 0.00 & 0.01 & 0.01 & 0.00 & 0.01 & 0.02 & 0.00 \\
\hline $\mathbf{K}_{2} \mathbf{O}$ & 0.00 & 0.01 & 0.01 & 0.00 & 0.02 & .03 & 0.08 & 0.11 & 0.05 \\
\hline$\Sigma w t \%$ & 99.22 & 99.16 & 99.28 & 99.28 & 99.54 & 98.90 & 99.65 & 99.70 & 99.28 \\
\hline $\mathbf{S i}$ & 0.98 & 0.99 & 0.99 & 0.99 & 0.99 & 0.98 & 1.00 & 1.00 & 0.99 \\
\hline Ti & 0.00 & 0.00 & 0.00 & 0.00 & 0.00 & 0.00 & 0.00 & 0.00 & 0.00 \\
\hline Al & 0.00 & 0.00 & 0.00 & 0.00 & 0.01 & 0.01 & 0.02 & 0.02 & 0.01 \\
\hline $\mathrm{Cr}$ & 0.00 & 0.00 & 0.00 & 0.00 & 0.00 & 0.00 & 0.00 & 0.00 & 0.00 \\
\hline $\mathrm{Fe}^{+3}$ & 0.00 & 0.00 & 0.00 & 0.00 & 0.00 & 0.00 & 0.00 & 0.00 & 0.00 \\
\hline $\mathrm{Fe}^{+2}$ & 0.18 & 0.18 & 0.18 & 0.18 & 0.08 & 0.10 & 0.09 & 0.10 & 0.08 \\
\hline Mn & 0.00 & 0.00 & 0.00 & 0.00 & 0.00 & 0.00 & 0.00 & 0.00 & 0.00 \\
\hline Mg & 1.85 & 1.83 & 1.83 & 1.83 & 1.92 & 1.92 & 1.88 & 1.86 & 1.90 \\
\hline $\mathrm{Ni}$ & 0.09 & 0.01 & 0.01 & 0.01 & 0.01 & 0.01 & 0.01 & 0.01 & 0.01 \\
\hline $\mathrm{Ca}$ & 0.00 & 0.00 & 0.00 & 0.00 & 0.00 & 0.00 & 0.00 & 0.01 & 0.00 \\
\hline $\mathrm{Na}$ & 0.00 & 0.00 & 0.00 & 0.00 & 0.00 & 0.00 & 0.00 & 0.00 & 0.00 \\
\hline $\mathbf{K}$ & 0.00 & 0.00 & 0.00 & 0.00 & 0.00 & 0.00 & 0.00 & 0.00 & 0.00 \\
\hline $\begin{array}{l}\Sigma \\
\text { cation }\end{array}$ & 3.01 & 3.00 & 3.00 & 3.00 & 3.00 & 3.01 & 2.99 & 2.98 & 2.99 \\
\hline Fo & 91 & 91 & 91 & 91 & 96 & 95 & 95 & 95 & 96 \\
\hline Fa & 9 & 9 & 9 & 9 & 4 & 5 & 4 & 5 & 4 \\
\hline$\# \mathbf{M g}$ & 91 & 91 & 91 & 91 & 96 & 95 & 95 & 95 & 96 \\
\hline
\end{tabular}

$1200^{\circ} \mathrm{C}$ to $1750^{\circ} \mathrm{C}$ during a time that goes from seconds up to a few minutes. On rare occasions, when the temperature reached $1900^{\circ} \mathrm{C}$, the sample was melted after few seconds. In this study, the time required to melt the crystals of olivine was from a few seconds up to a 1 minute. Using the phase diagram by Nagahara et al. (1994) we inferred a temperature range of our experiments between $1400^{\circ} \mathrm{C}$ to less than 1900 ${ }^{\circ} \mathrm{C}$. Temperature during experiments has been measured by thermocouples (e.g. Hewins et al., 1982) and derived from theoretical arguments considering energy balance (Blander et al., 1976; Eisenhour et al., 1994). When the precursor material is coarse-grained, $\mathrm{BO}$ textures are formed at higher temperatures of $2100{ }^{\circ} \mathrm{C}$ (Connolly et al., 1998). As was pointed out by Varela et al. (2006), the formation of classic type $\mathrm{BO}$ chondrules by melting of solid precursors requires the consideration of several aspects: (1) complete melting plus overheating that will eliminate all nuclei, (2) cooling of the system: homogeneous nucleation will take place only after some undercooling, (3) the first nucleus has to crystallize instantaneously to form one crystal for the whole droplet, giving rise to the $\mathrm{BO}$ chondrule.

\subsection{Porphyritic-like samples}

Carbon is present in all types of chondrites. Carbonaceous chondrites have 3 to $5 \mathrm{wt} \%$ of carbon, the ordinary 


\section{Crystal distance $(\mu \mathrm{m})$}

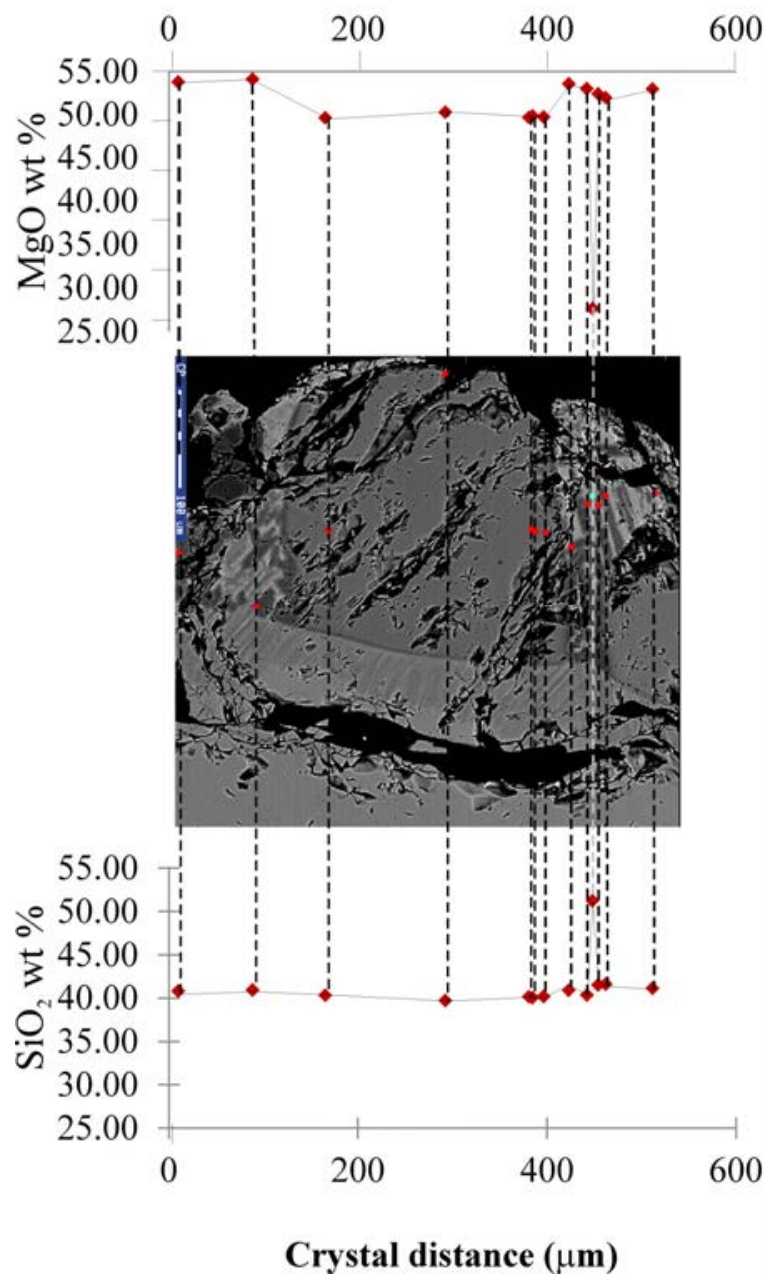

Figure 10. Backscattered electron image in a close-up of Figure 9. The points in the image are the places where chemical analyses were made with EPMA. The graphs show related variations in the content of $\mathrm{SiO}_{2}$ and $\mathrm{MgO}$ against distance.

chondrites may contain $1.5 \mathrm{wt} \%$ or less (e.g. Kerridge, 1985), while the enstatite chondrites may comprise 0.056 to $0.5 \mathrm{wt} \%$ (Moore and Lewis, 1966). Carbon content is organic matter, carbonates, and minor amounts of presolar grain materials such as diamond, graphite, and silicon carbide (Gilmour, 2003). A straightforward association was observed between the distribution of organic matter and hydrous clay minerals, suggesting that the production of clays by aqueous processes influenced the distribution of organic matter in meteorites (Gilmour, 2003).

The contribution of activated charcoal with a certain content of clay in samples EX1\#94 and EX1\#95 was a factor that contributed to the formation of the porphyritic texture. Clay minerals contain a greater amount of $\mathrm{SiO}_{2}$, which contributed to the formation of pigeonite. However, pigeonite occurred near the surface, where the oxygen in the atmosphere was higher compared to the reducing atmosphere (Figure 9). Is the presence of clays with carbon
Table 6. Representative pyroxene compositions.

\begin{tabular}{|c|c|c|c|c|c|}
\hline $\begin{array}{l}\text { Sample } \\
\text { wt. } \%\end{array}$ & $\begin{array}{l}\text { EX1\# } \\
94 \mathrm{e}-14\end{array}$ & $\begin{array}{l}\text { EX1\# } \\
\text { 94p-18 }\end{array}$ & $\begin{array}{l}\text { EX1\# } \\
\text { 94p-24 }\end{array}$ & $\begin{array}{l}\text { EX1\# } \\
\text { 94p-26 }\end{array}$ & $\begin{array}{l}\text { EX1\# } \\
\text { 94p-33 }\end{array}$ \\
\hline $\mathrm{SiO}_{2}$ & 51.21 & 52.03 & 53.44 & 52.12 & 52.40 \\
\hline $\mathrm{TiO}_{2}$ & 0.29 & 0.35 & 0.36 & 0.36 & 0.35 \\
\hline $\mathbf{A l}_{2} \mathbf{O}_{3}$ & 8.68 & 9.85 & 10.53 & 9.55 & 9.26 \\
\hline \multicolumn{6}{|l|}{$\mathrm{Cr}_{2} \mathrm{O}_{3}$} \\
\hline $\mathrm{FeO}$ & 7.95 & 9.32 & 8.01 & 9.46 & 7.86 \\
\hline MnO & 0.06 & 0.12 & 0.09 & 0.09 & 0.08 \\
\hline MgO & 27.64 & 23.13 & 23.69 & 23.86 & 26.17 \\
\hline $\mathrm{NiO}$ & 0.15 & 0.07 & 0.13 & 0.08 & 0.13 \\
\hline $\mathrm{CaO}$ & 2.17 & 2.63 & 2.57 & 2.50 & 2.34 \\
\hline $\mathrm{Na}_{2} \mathrm{O}$ & 0.15 & 0.09 & 0.23 & 0.11 & 0.09 \\
\hline $\mathbf{K}_{2} \mathbf{O}$ & 1.09 & 0.89 & 1.22 & 0.61 & 0.60 \\
\hline$\Sigma w t \%$ & 99.38 & 98.49 & 100.26 & 98.74 & 99.33 \\
\hline Si & 1.82 & 1.86 & 1.87 & 1.86 & 1.85 \\
\hline $\mathbf{T i}$ & 0.01 & 0.01 & 0.01 & 0.01 & 0.01 \\
\hline $\mathbf{A} \mathbf{l}^{\mathbf{T}}$ & 0.18 & 0.28 & 0.30 & 0.26 & 0.23 \\
\hline $\mathbf{A l}^{\mathrm{M} 1}$ & 0.18 & 0.14 & 0.13 & 0.14 & 0.15 \\
\hline $\mathrm{Cr}$ & 0.00 & 0.00 & 0.00 & 0.00 & 0.00 \\
\hline $\mathrm{Fe}^{+3}$ & 0.03 & 0.00 & 0.00 & 0.00 & 0.00 \\
\hline $\mathrm{Fe}^{+2}$ & 0.20 & 0.28 & 0.24 & 0.29 & 0.23 \\
\hline Mn & 0.00 & 0.00 & 0.00 & 0.00 & 0.00 \\
\hline Mg & 1.46 & 1.23 & 1.24 & 1.27 & 1.37 \\
\hline $\mathrm{Ni}$ & 0.00 & 0.00 & 0.00 & 0.00 & 0.00 \\
\hline $\mathbf{C a}$ & 0.08 & 0.10 & 0.10 & 0.10 & 0.09 \\
\hline $\mathbf{N a}$ & 0.01 & 0.01 & 0.02 & 0.02 & 0.01 \\
\hline $\mathbf{K}$ & 0.03 & 0.02 & 0.03 & 0.01 & 0.01 \\
\hline$\Sigma$ cation & 4.01 & 3.94 & 3.93 & 3.95 & 3.96 \\
\hline Wo & 5 & 6 & 6 & 6 & 5 \\
\hline En & 82 & 76 & 79 & 77 & 81 \\
\hline Fs & 13 & 18 & 15 & 18 & 14 \\
\hline \#Mg & 86 & 82 & 84 & 82 & 86 \\
\hline
\end{tabular}

Table 7. Representative glass composition of sample EX1\#94.

\begin{tabular}{|c|c|c|c|c|c|}
\hline $\begin{array}{l}\text { Sample } \\
\text { wt. } \% \\
\end{array}$ & $\begin{array}{l}\text { EX1\# } \\
\text { 94-g-28 }\end{array}$ & $\begin{array}{l}\text { EX1\# } \\
\text { 94-g-29 } \\
\end{array}$ & $\begin{array}{l}\text { EX1\# } \\
\text { 94-g-30 }\end{array}$ & $\begin{array}{l}\text { EX1\# } \\
\text { 94-g-31 } \\
\end{array}$ & $\begin{array}{l}\text { EX1\# } \\
\text { 94-g-32 }\end{array}$ \\
\hline $\mathrm{SiO}_{2}$ & 50.14 & 50.09 & 50.61 & 50.04 & 49.82 \\
\hline $\mathrm{TiO}_{2}$ & 0.24 & 0.24 & 0.25 & 0.25 & 0.25 \\
\hline $\mathbf{A l}_{2} \mathbf{O}_{3}$ & 6.91 & 7.00 & 7.00 & 6.95 & 6.65 \\
\hline \multicolumn{6}{|l|}{$\mathrm{Cr}_{2} \mathrm{O}_{3}$} \\
\hline \multicolumn{6}{|l|}{$\mathrm{Fe}_{2} \mathrm{O}_{3}$} \\
\hline FeO & 7.42 & 7.50 & 7.49 & 7.34 & 7.40 \\
\hline MnO & 0.09 & 0.09 & 0.06 & 0.10 & 0.07 \\
\hline MgO & 32.21 & 31.90 & 32.18 & 32.19 & 33.65 \\
\hline $\mathrm{NiO}$ & 0.23 & 0.19 & 0.19 & 0.17 & 0.20 \\
\hline $\mathrm{CaO}$ & 1.74 & 1.78 & 1.75 & 1.72 & 1.62 \\
\hline $\mathrm{Na}_{2} \mathrm{O}$ & 0.13 & 0.08 & 0.10 & 0.11 & 0.07 \\
\hline $\mathrm{K}_{2} \mathrm{O}$ & 0.60 & 0.56 & 0.59 & 0.63 & 0.55 \\
\hline$\Sigma$ wt. $\%$ & 99.70 & 99.43 & 100.23 & 99.50 & 100.28 \\
\hline
\end{tabular}




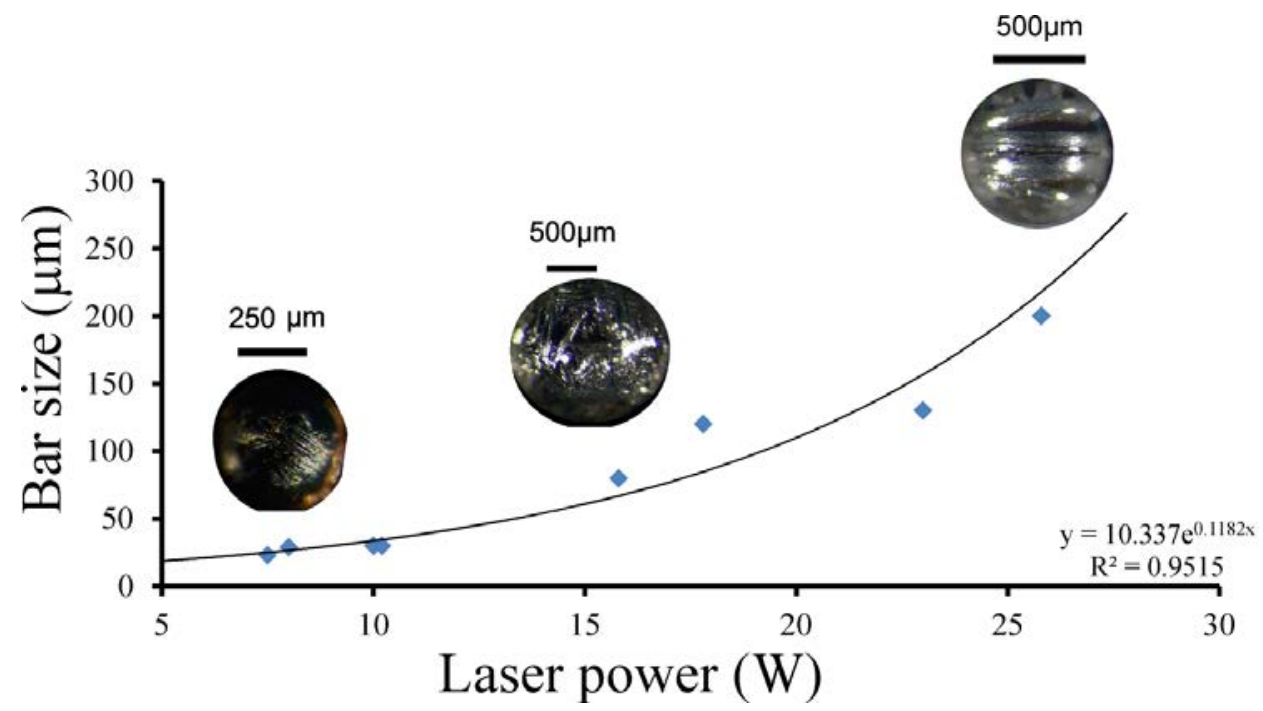

Figure 11. X-Y diagram comparing the final power of the laser beam used to melt olivine crystals (x-axis) versus the width of the olivine bars of the experiments (y-axis). The selected photos of the samples give details of the size of the bars (e.g., sample EX1\#67 is located at 8W, sample EX1\# 61 at $15.8 \mathrm{~W}$ and sample EX1\# 62 at $25.8 \mathrm{~W})$.

compounds important for the formation of porphyritic chondrules? If so, the contribution of carbon and clay are important phases to be considered in the formation of porphyritic chondrules, mainly because these type of chondrules are very abundant in chondrites (ranging from 50 to $80 \mathrm{vol} \%$ of the total of chondrules). Thus, in future work it will be crucial to control the composition and proportion of clay as well as the carbon-based compounds. The processes of formation of chondrules were high temperature events and surely the compounds of carbon were volatilized in the spot areas where they were formed.

\section{Conclusions}

From this preliminary set of experiments, we have derived the following constraints that will be further explored in our future experiments:

- The width and amount of olivine bars are related to the energy of irradiation, i.e., the more energy used (higher temperature), the bars of olivine are fewer and wider in the sample. However, these bars are also larger and thicker. This is due to the fact that there are fewer crystallization nuclei that compete for the available matter.

- In spite of the fact that the exact temperatures reached during the experiments could not be determined, the textures compared with those reported in the literature and suggest that the range of temperature reached during the experiments was between 1400 up to $1900{ }^{\circ} \mathrm{C}$.

- The textures obtained in these experiments are similar to the barred olivine, olivine and pyroxene porphyritic chondrules of ordinary chondrites.
- The formation of porphyritic-like chondrules occurred in two samples with activated carbon contaminated with clays. These conditions promoted a reducing environment with increasing content of $\mathrm{SiO}_{2}$ that favors pyroxene formation.

\section{Acknowledgments}

This project is possible thanks to the support of the projects of CONACYT No. 43227 and No. 128228, PhD. fellowship No. 177354 and the projects PAPIIT No. IA101312 and IA105515. The authors gratefully acknowledge the technical support provided by the group of the Laboratorio de Fotónica de Microondas headed by Dr. Oleg V. Kolokoltsev at Centro de Ciencias Aplicadas y Desarrollo Tecnológico, UNAM and by the group of the Laboratory of Óptica Cuántica led by Dr. Alfred U'ren and Héctor Cruz Ramírez at Instituto de Ciencias Nucleares, UNAM. Also, we thank the Technical Academic Jose Rangel Gutiérrez at Taller Mecánico y Eléctrico at Instituto de Ciencias Nucleares, UNAM. We thank María Eugenia Varela and María del Sol Hernández-Bernal for their comments that allowed us to greatly improve the content and the presentation of the paper. We are thankful with the doctors Alejandro Heredia Barbero and Maria Colín García for the effort made to publish this special issue and for their comments to improve our paper.

\section{References}

Alexander, C.M.O., Grossman, J.N., Ebel, D.S., Ciesla, F.J., 2008, The Formation Conditions of Chondrules and Chondrites: Science, 320, 1617-1619, doi: 10.1126/science.1156561. 
Beitz, E., Blum, J., Mathieu, R., Pack, A., Hezel, D.C., 2013, Experimental investigation of the nebular formation of chondrule rims and the formation of chondrite parent bodies: Geochimica et Cosmochimica Acta, 116, 41-51.

Bernal, J.P., Lozano-Santacruz, R., 2005, Characterization of a new set of eight geochemical reference materials for XRF major and trace element analysis: Revista Mexicana de Ciencias Geológicas, 22, 329-344.

Blander, M., Planner, H.N., Keil, K., Nelson, L.S., Richardson, N.L., 1976, The origin of chondrules: experimental investigation of metastable liquids in the system $\mathrm{Mg} 2 \mathrm{SiO} 4-\mathrm{SiO} 2$ : Geochimica et Cosmochimica Acta, 40, 889-896.

Boss, A., 1996, A concise guide to chondrule formation models, in Hewins, R., Jones, R., Scott, E. (eds.), Chondrules and the protoplanetary disk: Cambridge, UK, Cambridge University Press, 257-263.

Connolly, H.C., Hewins, R.H., 1996, Constraints on chondrule precursors from experimental data, in Hewins, R., Jones, R., Scott, E. (eds.), Chondrules and the Protoplanetary Disk: Cambridge, UK, Cambridge University Press, 129-135.

Connolly, H.C., Love, S.G., 1998, The Formation of Chondrules: Petrologic Tests of the Shock Wave Model: Science, 280, 62-67, doi: 10.1126/ science.280.5360.62.

Connolly, H.C., Jr., Jones, B.D., Hewins, R.H., 1991, The Effect of Precursor Grain Size on Chondrule Textures: LPI Contributions, 766, 49.

Connolly, H.C., Jr., Jones, B.D., Hewins, R.H., 1998, The flash melting of chondrules: an experimental investigation into the melting history and physical nature of chondrule precursors: Geochimica et Cosmochimica Acta, 62, 2725-2735, doi: 10.1016/S00167037(98)00176-8.

Connelly, J.N., Bizzarro, M., Krot, A.N., Nordlund, Å., Wielandt, D., Ivanova, M.A., 2012, The Absolute Chronology and Thermal Processing of Solids in the Solar Protoplanetary Disk: Science, 338, 651-655, doi: 10.1126/science.1226919.

Desch, S., Morris, M., Connolly, H., Boss, A., 2010, The Importance of Experiments: Constraints on Chondrule Formation Models (resume), in Chondrules: Their Role in Early Solar System: New York, New York, Lunar and Planetary Science Institute 8008.

Eisenhour, D.D., Daulton, T.L., Buseck, P.R., 1994, Electromagnetic heating in the early solar nebula and the formation of chondrules: Science, 265, 1067-1070.

Faure, F., Trolliard, G., Nicollet, C., Montel, J.M., 2003a, A developmental model of olivine morphology as a function of the cooling rate and the degree of undercooling: Contributions to Mineralogy and Petrology, 145, 251-263.

Faure, F., Trolliard, G., Soulestin, B., 2003b, TEM investigation of forsterite dendrites: American Mineralogist, 88, 1241-1250.

Gilmour, I., 2003, Structural and isotopic analysis of organic matter in carbonaceous chondrites: Treatise on Geochemistry, 1, 269-290.

Hernández-Bernal, M. del S., Solé, J., 2010, Edades K-Ar y Pb-Pb de condros individuales de condritas ordinarias mexicanas como trazadores de eventos de impacto prolongadas: Revista mexicana de Ciencias Geológicas, 27, 123-133.

Hewins, R.H., 1997, Chondrules: Annual Review of Earth and Planetary Sciences, 25, 61-83.

Hewins, R.H., Fox, G.E., 2004, Chondrule textures and precursor grain size: an experimental study: Geochimica et Cosmochimica Acta, 68, 917-926.

Hewins, R.H., Connolly, H.C., Lofgren Jr, G.E., Libourel, G., 2005, Experimental Constraints on Chondrule Formation, in Chondrites and the Protoplanetary Disk, 286.

Hewins, R.H., Klein, L.C., Fasano, B.V., 1982, Conditions of formation of pyroxene excentroradial chondrules (abstract), in Lunar and Planetary Science Conference, 12th, Houston, Texas: New York and Oxford, Pergamon Press, Proceedings, Section 2. (A82-31677 15-91), 1123-1133.

Kerridge, J.F., 1985, Carbon, hydrogen and nitrogen in carbonaceous chondrites: Abundances and isotopic compositions in bulk samples: Geochimica et Cosmochimica Acta, 49, 1707-1714.

King, E.A., 1983, Chondrules and Their Origins: Houston, Texas, Lunar and Planetary Institute, 1983, 387 p.

Lofgren, G., 1989, Dynamic crystallization of chondrule melts of porphyritic olivine composition: Textures experimental and natural: Geochimica et Cosmochimica Acta, 53, 461-470.

Lofgren, G., 1996, A Dynamic Crystallization Model for Chondrule Melts, in Hewins, R.H., Jones, R.H., Scott, E.R.D. (eds), Chondrules and the protoplanetary disk: Cambridge, Cambridge University Press, 187-196.

Lofgren, G., Lanier, A.B., 1988, Dynamic crystallization experiments on melts of barred olivine chondrule composition: Origin of their textural diversity: Meteoritics, 23, 285.

Moore, C.B., Lewis, C.F., 1966, The distribution of total carbon content in enstatite chondrites: Earth and Planetary Science Letters, 1, 376-378.

Morris, M.A., Desch, S.J., 2010, Thermal Histories of Chondrules in Solar Nebula Shocks: The Astrophysical Journal, 722, 1474, doi: 10.1088/0004-637X/722/2/1474.

Nagahara, H., Kushiro, I., Mysen, B.O., 1994, Evaporation of olivine: Low pressure phase relations of the olivine system and its implication for the origin of chondritic components in the solar nebula: Geochimica et Cosmochimica Acta, 58, 1951-1963.

Nelson, L.S., Blander, M., Skaggs, S.R., Keil, K., 1972, Use of a CO laser to prepare chondrule-like spherules from supercooled molten oxide and silicate droplets: Earth and Planetary Science Letters, 14, 338-344, doi: 10.1016/0012-821X(72)90133-1.

Nimz, G.J., Cameron, K.L., Niemeyer, S., 1993, The La Olivina pyroxenite suite and the isotopic compositions of mantle basalts parental to the Mid-Cenozoic arc volcanism of northern Mexico: Journal of Geophysical Research: Solid Earth (1978-2012), 98, 6489-6509.

Rubin, A.E., 2000, Petrologic, geochemical and experimental constraints on models of chondrule formation: Earth-Science Reviews, 50, 3-27, doi: 10.1016/S0012-8252(99)00067-7.

Scott, E.R.D., 2007, Chondrites and the Protoplanetary Disk: Annual Review of Earth and Planetary Sciences, 35, 577-620, doi: 10.1146/ annurev.earth.35.031306.140100.

Solé Viñas, J., 2004, Método K-Ar y U-Th-He del Instituto de Geología UNAM: Disponible en: http://www.geologia.unam. mx:8080/igl/index.php/parks/laboratorios/laboratorios-degeoquimica/geocronologia-k-ar/639-breves-ideas-sobre-la-teoriadel-geocronometro-k-ar (consulted on November 24, 2015).

Varela, M.E., Kurat, G., Zinner, E., 2006, The primary liquid condensation model and the origin of barred olivine chondrules: Icarus, 184, 344-364, doi: 10.1016/j.icarus.2006.05.009.

Wasson, J.T., 1996, Chondrule formation: Energetics and length scales, in Hewins, R.H., Jones, R.H., Scott, E.R.D. (eds), Chondrules and the protoplanetary disk: Cambridge, Cambridge University Press, 45-54.

Yu, Y., Hewins, R.H., Wang, J., 2003, Experimental study of evaporation and isotopic mass fractionation of potassium in silicate melts: Geochimica et Cosmochimica Acta, 67, 773-786.

Zolensky, M.E., Nakamura, K., Gounelle, M., Mikouchi, T., Kasama, T., Tachikawa, O., Tonui, E., 2002, Mineralogy of Tagish Lake: An ungrouped type 2 carbonaceous chondrite: Meteoritics \& Planetary Science, 37, 737-761.

Manuscript received: January 4, 2014

Corrected manuscript received: February 25, 2014

Manuscript accepted: March 17, 2015 